\title{
Pengaruh Suhu Dan Lama Penyeduhan Terhadap Kualitas Minuman Teh Daun Kersen (Muntingia calabura $\mathbf{L}$.)
}

(The Influence Of Temperature And Length Of Brewing On The Quality Of Cherry Leaf Tea Drink (Muntingia calabura L.))

\author{
Nidhamul Fikri $^{1}$, Rasdiansyah $^{1^{*}}$, Fahrizal $^{1}$ \\ ${ }^{1}$ Program Studi Teknologi Hasil Pertanian, Fakultas Pertanian, Universitas Syiah Kuala \\ *Corresponding author: rasdiansyah@unsyiah.ac.id
}

\begin{abstract}
Abstrak. Salah satu tanaman yang telah lama dibudidayakan di Indonesia adalah teh. Teh mengandung berbagai manfaat yang baik untuk tubuh manusia, diantaranya sebagai antioksidan, memperbaiki sel yang rusak, menghaluskan kulit, melangsingkan tubuh, mencegah kanker, mencegah penyakit jantung, mengurangi kolesterol dalam darah, dan melancarkan sirkulasi darah. Penelitian ini bertujuan untuk mengetahui kualitas minuman teh daun kersen berdasarkan pengaruh suhu dan lama penyeduhan. Penelitian ini menggunakan Rancangan Acak Kelompok (RAK) faktorial yang terdiri dari 2 faktor. Faktor 1 yaitu pengaruh suhu $(\mathrm{P})$ yang terdiri atas 3 taraf yaitu $\mathrm{P} 1=80^{\circ} \mathrm{C}, \mathrm{P} 2=90^{\circ}$, dan $\mathrm{P} 3=100^{\circ} \mathrm{C}$. Faktor 2 yaitu lama penyeduhan teh yang terdiri atas 3 taraf yaitu $\mathrm{W} 1=$ 6 menit, W2 $=9$ menit dan W3= 12 menit. Hasil penelitian menunjukan bahwa suhu penyeduhan bepengruh nyata terhadap $\operatorname{tanin}(0,09 \%)$, sensori aroma (Netral) dan berpengaruh sangat nyata terhadap sensori warna (Netral). Lama penyeduhan berpengaruh nyata terhadap aktivitas antioksidan $(3,98 \%)$ dan berpengaruh sangat nyata terhadap sensori rasa teh (Netral). Kombinasi antara suhu penyeduhan dan lama penyeduhan $90^{\circ} \mathrm{C}$ selama 9 menit merupakan perlakuan terbaik pada minuman teh daun kersen.
\end{abstract}

Kata kunci: Teh, Daun Kersen, Muntingia Calabura L.

Abstract. One of the plants that has long been cultivated in Indonesia is tea. Tea contains various benefits that are good for the human body, including as an antioxidant, repairing damaged cells, smoothing the skin, slimming the body, preventing cancer, preventing heart disease, reducing cholesterol in the blood, and improving blood circulation. This study aims to determine the quality of cherry leaf tea based on the effect of temperature and brewing time. This study used a factorial Randomized Block Design (RAK) consisting of 2 factors. Factor 1 is the effect of temperature $(P)$ which consists of 3 levels, namely $P 1=80^{\circ} \mathrm{C}, P 2=90^{\circ} \mathrm{C}$, and $P 3=100^{\circ} \mathrm{C}$. Factor 2 is the length of tea brewing which consists of 3 levels, namely $W 1=6$ minutes, $W 2=9$ ssminutes and W3 $=12$ minutes. The results showed that the brewing temperature had a significant effect on tannins (0.09\%), aroma sensory (Neutral) and very significant effect on color sensory (Neutral). The brewing time has a significant effect on antioxidant activity (3.98\%) and has a very significant effect on the sensory taste of tea (Neutral). The combination of the brewing temperature and the brewing time of $90^{\circ} \mathrm{C}$ for 9 minutes is the best treatment for cherry leaf tea drinks.

Keywords: Tea, Cherry Leaf, Muntingia Calabura L.

\section{PENDAHULUAN}

Indonesia merupakan negara yang dikenal dengan keanekaragaman tanamannya. Salah satu tanaman yang telah lama dibudidayakan di Indonesia adalah teh. Sejak lama tumbuhan teh telah diolah menjadi minuman yang menyegarkan dan dapat dinikmati oleh semua kalangan (Anjarsari, 2016). Teh mengandung berbagai manfaat yang baik untuk tubuh manusia, diantaranya sebagai antioksidan, memperbaiki sel yang rusak, menghaluskan kulit, melangsingkan tubuh, mencegah kanker, mencegah penyakit jantung, mengurangi kolesterol dalam darah, dan melancarkan sirkulasi darah. Manfaat ini diperoleh karena teh mengandung senyawa-senyawa seperti polifenol, theofilin, flavonoid atau metilxantin, $\operatorname{tanin}$, vitamin $\mathrm{C}$ dan E, catechin serta minereal seperti Zn, Se, Mo, Ge, dan Mg (Soraya, 2007).

Minuman teh tidak hanya dibuat dari daun tanaman teh (Camellia sinensis), namun juga dapat dibuat dari daun tanaman lain salah satunya adalah daun kersen. Daun kersen 
mengandung senyawa flavonoid, tanin, triterpene, saponin, polifenol yang menunjukkan adanya aktivitas antioksidan (Binawati dan Amilah, 2013). Pada umumnya masyarakat mengkonsumsi daun kersen dengan cara direbus (Ilkafah, 2018). Masyarakat sering memanfaatkan daun kersen untuk mengobati beberapa penyakit diantaranya, melindungi fungsi otot jantung, obat diabetes, anti hipertensi, anti kolesterol, anti inflamasi, anti tumor, dan anti septik (Sudarmanto, 2015).

Beberapa penelitian yang sudah dilakukan sebelumnya tentang penyeduhan teh menyatakan bahwa lama penyeduhan dan suhu penyeduhan sangat mempengaruhi kualitas teh yang dihasilkan karena semakin lama penyeduhan maka senyawa yang terdapat di dalam teh akan semakin terekstrak.

\section{METODE PENELITIAN}

Penelitian ini dilaksanakan di Laboratorium Analisis Pangan dan Hasil Pertanian dan Laboratorium Uji Sensori di Jurusan Teknologi Hasil Pertanian Fakultas Pertanian Universitas Syiah Kuala.

\section{BAHAN DAN METODE}

\section{Alat dan Bahan}

Alat-alat yang digunakan pada penelitian ini terdiri dari: ember, terpal jemur, ayakan 20 mesh, timbangan analitik, blender, baskom, panci, termometer, sendok, beaker glass, kertas saring, tabung reaksi, gelas ukur, pipet tetes, kertas saring, erlenmeyer, saringan, desikator, kuvet, kertas label dan $U V$-Vis Spektofotometer

Bahan-bahan yang digunakan pada penelitian ini terdiri dari: daun kersen yang diperoleh dari Banda Aceh dan Aceh Besar, air, larutan 1,1-dphynil-2-picrylhdrazil (DPPH) dalam methanol $0,2 \mathrm{mM}, 0,3 \mathrm{ml} \mathrm{FeCl}{ }_{3}, \mathrm{Na}_{2} \mathrm{CO}_{3}$, standar asam galat, kloroform, asam klorogenat, etanol.

\section{Metode Penelitian}

Penelitian ini menggunakan rancangan acak kelompok (RAK) faktorial yang terdiri dari 2 faktor. Faktor 1 yaitu pengaruh suhu $(\mathrm{P})$ yang terdiri atas 3 taraf yaitu $\mathrm{P} 1=80^{\circ} \mathrm{C}, \mathrm{P} 2=90^{\circ} \mathrm{C}$ dan $\mathrm{P} 3=100^{\circ} \mathrm{C}$. Faktor 2 yaitu lama penyeduhan teh yang terdiri atas 3 taraf yaitu $\mathrm{W} 1=6$ menit, $\mathrm{W} 2=9$ menit dan $\mathrm{W} 3=12$ menit. Setiap perlakuan dilakukan pengulangan sebanyak 3 kali, sehingga seluruh total satuan percobaan yang akan dilakukan sebanyak 27 satuan percobaan. Apabila hasil ANOVA berpengaruh nyata, maka dilakukan uji lanjut yaitu menggunakan metode Duncan Multiple Range -Test (DMRT)

\section{Prosedur Pembuatan Teh Daun Kersen}

Pada penelitian ini pembuatan teh daun kersen terdiri dari 3 tahap, meliputi pembuatan teh daun kersen, penyeduhan, dan analisis produk. 


\section{Pembuatan Teh Daun Kersen}

Adapun cara pembuatan teh daun kersen yaitu pilih daun kersen yang segar, berwarna hijau muda dan tidak dimakan ulat, kemudian dicuci hingga bersih. Selanjutnya daun yang sudah dicuci ditaruh di wadah yang besar, kemudian dijemur kembali sampai kering selama 35 hari. Setelah itu dilakukan dan dimasukkan ke dalam kemasan teh celup sebanyak 2 gram untuk diseduh.

\section{Prosedur Penyeduhan Teh Kersen}

Adapun cara penyeduhan teh daun kersen yaitu teh celup daun kersen diseduh menggunakan air panas sesuai perlakuan $\left(80^{\circ} \mathrm{C}, 90^{\circ} \mathrm{C}\right.$ dan $\left.100^{\circ} \mathrm{C}\right)$ dengan lama penyeduhan sesuai dengan perlakuan yang sudah ditentukan $(6,9$ dan 12 menit).

\section{Analisis Karakteristik Teh Daun Kersen}

Analisis yang dilakukan pada teh daun kersen terdiri dari analisis fitokimia dan analisis sensori pada teh daun kersen. Analisis fitokimia meliputi analisis aktivitas antioksidan (Atanassova, 2011), analisis kadar tanin (Suryaningrum, 2007) dan uji organoleptik secara hedonik terhadap warna, aroma, rasa, dan penerimaan keseluruhan (Tandean, 2016).

\section{HASIL DAN PEMBAHASAN}

\section{Kadar Tanin}

Kadar tanin teh daun kersen pada penelitian ini berada pada rentang $0,01 \%-0,18 \%$ dengan nilai rata-rata sebesar 0,09\%. Berdasarkan hasil Analysis of Variance (ANOVA) menunjukkan bahwa yang berpengaruh sangat nyata $(\mathrm{P} \leq 0,01)$ terhadap kadar tannin hanya suhu penyeduhan teh daun kersen (P3), sedangkan lama penyeduhan (W) dan interaksi kedua perlakuan $(\mathrm{PW})$ berpengaruh tidak nyata $(\mathrm{P} \geq 0,05)$ terhadap kadar tanin. Adapun grafik yang menunjukkan kadar tanin terhadap teh daun kersen dapat dilihat pada Gambar 1.

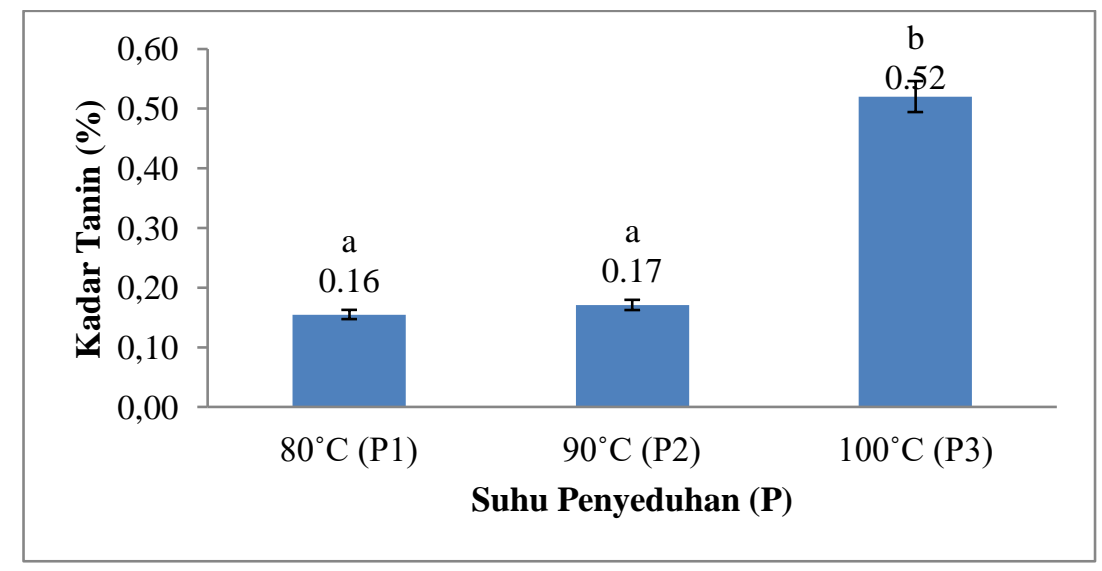

Gambar 1. Pengaruh suhu penyeduhan terhadap persentase (\%) kadar tanin teh daun kersen pada uji lanjut DMRT0.05 taraf $1=0,024$ taraf $2=$ $0,024, \mathrm{kk}=29.4 \%$, (Nilai yang di ikuti huruf yang sama menunjukan perbedaan yang sangat nyata). 
Pada Gambar 1 dapat dilihat bahwa adanya perbedaan pada suhu penyeduhan teh daun kersen. Kadar tanin mengalami peningkatan sebanding dengan suhu penyeduhan, tanin tertinggi diperoleh pada suhu penyeduhan pada $100^{\circ} \mathrm{C}$ yaitu $0,52 \%$. Tinggi rendahnya kadar tanin pada seduhan teh dipengaruhi oleh banyak sedikitnya kadar ekstrak dalam air seduhannya dikarenakan tanin erat hubungannya dengan rasa seduhan teh yang bisa memberikan rasa pahit pada seduhan tersebut (Jyosmita, 2015). Kadar tanin dalam teh dipengaruhi oleh beberapa faktor seperti tingkat kehalusan dan tingkat kepekatan warna pada teh (Fajriana, 2016). Kadar tanin dapat terekstrak maksimal pada suhu yang lebih tinggi (Nurul et al., 2018).

\section{Aktivitas Antioksidan}

Aktivitas antioksidan teh daun kersen pada penelitian ini berkisar antara 2,31\% - 3,86\% dengan nilai rata-rata sebesar 2,98\% (netral). Berdasarkan hasil Analysis of Variance (ANOVA) menunjukkan bahwa suhu penyeduhan $(\mathrm{P})$ berpengaruh tidak nyata $(\mathrm{P} \geq 0,05)$ sedangkan lama penyeduhan berpengaruh nyata $(\mathrm{P} \leq 0,05)$ dan interaksi kedua perlakuan $(\mathrm{PW})$ berpengaruh sangat nyata $(\mathrm{P} \leq 0,01)$ terhadap aktivitas antioksidan. Dari hasil sidik ragam maka harus dilakukan uji lanjut dengan menggunakan DMRT. Adapun grafik yang menunjukkan aktivitas antioksidan terhadap teh daun kersen dapat dilihat pada Gambar 2.

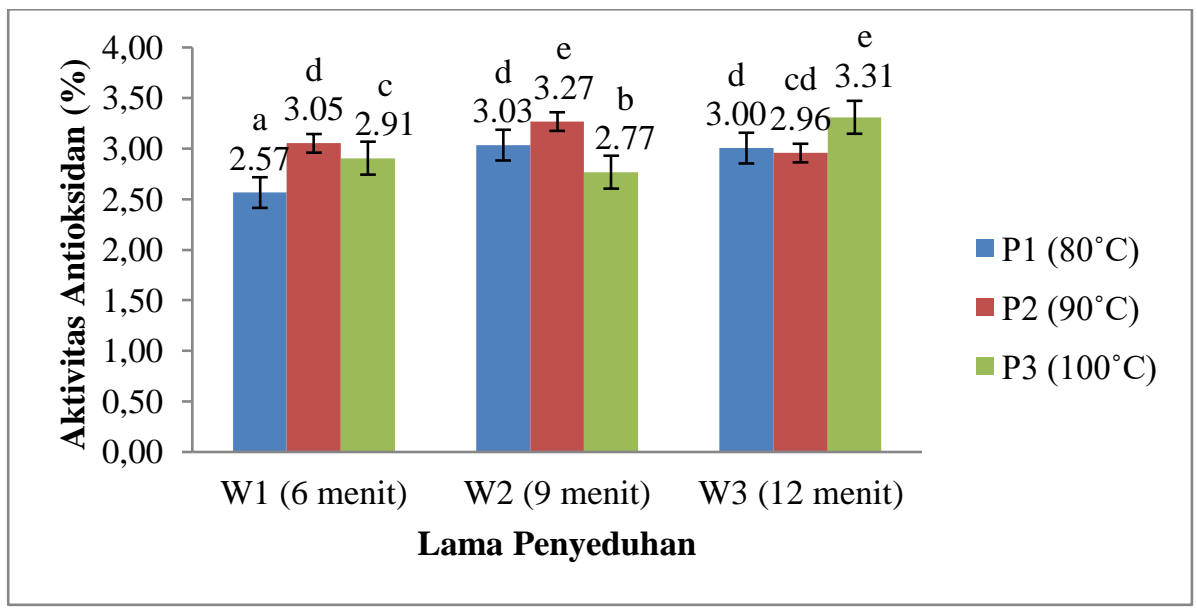

Gambar 2. Pengaruh interaksi antara suhu penyeduhan dan lama waktu penyeduhan terhadap persentase $(\%)$ aktivitas antioksidan teh daun kersen pada uji lanjut DMRT0.05 taraf $1=0,073$ taraf $2=$ $0,074, \mathrm{kk}=3.1 \%$, nilai yang diikuti huruf yang sama menunjukan perbedaan yang nyata.

Pada Gambar 2. Dapat dilihat bahwa interaksi suhu dan lama penyeduhan berpengaruh nyata terhadap aktivitas antioksidan teh daun kersen. Nilai aktivitas antioksidan yang paling tinggi pada penelitian ini diperoleh pada waktu penyeduhan 12 menit dengan suhu $100^{\circ} \mathrm{C}$ yaitu sebesar 3,31\%. Hal ini dikarenakan penyeduhan suhu $100^{\circ} \mathrm{C}$ selama 12 menit merupakan waktu optimum. Hasil ini sesuai dengan penelitian (Dewata et al,. 2017) yang menunjukkan bahwa antioksidan teh herbal daun alpukat tertinggi berada pada suhu $100^{\circ} \mathrm{C}$ selama 5 menit $18,55 \%$. Aktivitas antioksidan berbanding lurus dengan kenaikan temperatur karena semakin tinggi 
temperatur maka energi panas yang diberikan kepada sampel semakin tinggi dan senyawa yang terekstrak akan semakin banyak (Hapsari, 2013).

\section{Uji Organoleptik}

\section{Warna}

Pada uji organoleptik warna teh daun kersen yaitu 2,75\% (tidak suka) hingga 3,50\% (netral) dengan rata-rata 3,55 (suka). Hasil sidik ragam menunjukkan bahwa interaksi faktor pada teh kersen $(\mathrm{PW})$ berpengaruh sangat nyata $(\mathrm{P} \leq 0,01)$ terhadap nilai hedonik warna teh kersen. Adapun grafik yang menunjukkan organoleptik warna terhadap teh daun kersen dapat dilihat pada Gambar 3.

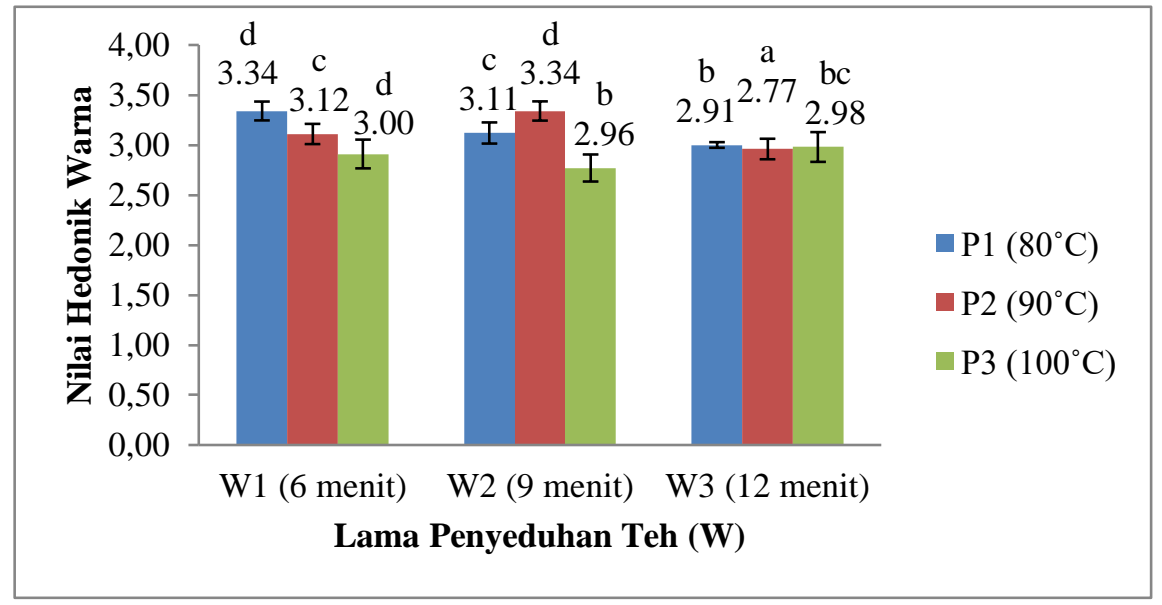

Gambar 3. Pengaruh lama waktu penyeduhan terhadap persentase (\%) warna teh daun kersen pada uji lanjut DMRT0.05 05 taraf $=0,126$ taraf $2=0,127$ taraf $3=0,128$ taraf $4=0,128$ taraf $5=0,173$ taraf $6=$ 0,176 taraf $7=0,176$ taraf $8=0,176 . \mathrm{kk}=3.78 \%$, nilai yang di ikuti huruf yang sama menunjukan perbedaan yang sangat nyata.

Perlakuan terbaik terhadap skor warna yang disukai oleh panelis adalah perlakuan pada suhu $80^{\circ} \mathrm{C}$ selama 6 menit $(\mathrm{P} 1 \mathrm{~W} 1)$ dan suhu $90^{\circ} \mathrm{C}$ selama 9 menit $(\mathrm{P} 2 \mathrm{~W} 2)$ dengan nilai uji skor warna yang tertingi yaitu 3,34\% yang berarti jumlah panelis yang menyukai dan tidak menyukai warna teh daun kersen yang diuji hampir sama. Teh kersen memiliki warna kuning pucat hingga kuning cerah. Ada 4 hal yang menyebabkan terjadinya perbedaan warna pada teh yaitu pigmen yang secara alami terdapat dalam tanaman, reaksi karamelisasi, warna gelap yang timbul akibat reaksi yang terjadi, dan reaksi oksidasi oleh adanya penambahan zat warna (Dewata, 2017).

\section{Aroma}

Pada uji organoleptik aroma teh daun kersen yaitu 2,55\% (tidak suka), 3,38\% (sangat suka) dengan rerata yaitu 2,99\% (suka). Sidik ragam menunjukkan bahwa suhu penyeduhan (P) berpengaruh nyata $(\mathrm{P} \leq 0,05)$ dan lama penyeduhan $(\mathrm{W})$ berpengaruh tidak nyata $(\mathrm{P} \geq 0,05)$ sedangkan interaksi kedua perlakuan $(\mathrm{PW})$ berpengaruh nyata $(\mathrm{P} \leq 0,05)$ terhadap sensori aroma 
teh daun kersen. Adapun grafik yang menunjukkan organoleptik aroma terhadap teh daun kersen dapat dilihat pada Gambar 4.

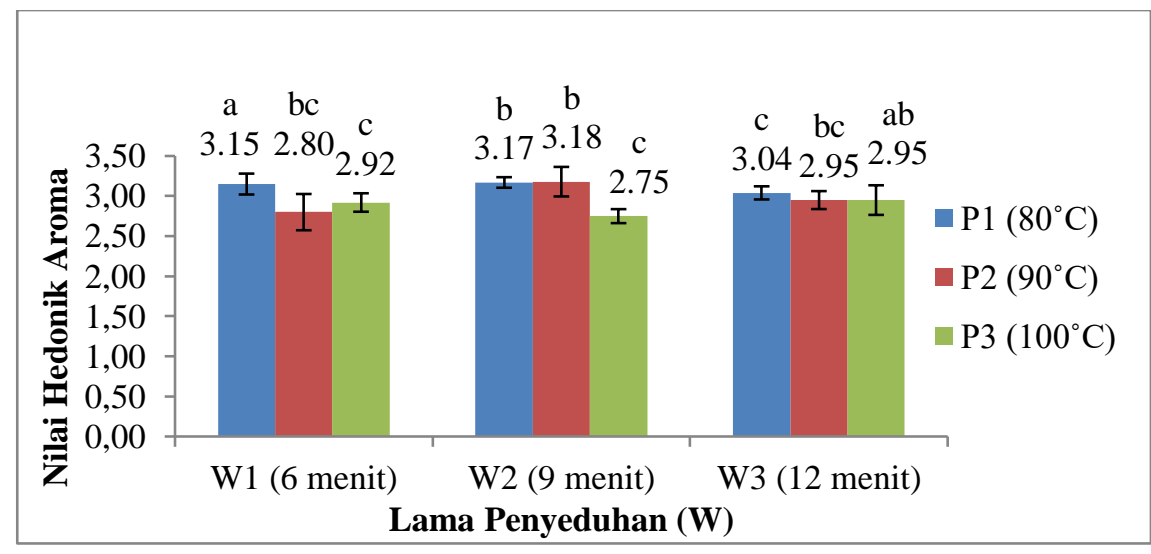

Gambar 4. Pengaruh lama waktu penyeduhan terhadap persentase (\%) aroma teh daun kersen pada uji lanjut DMRT0.05 taraf $=0,161$ taraf $2=0,162$ taraf $3=0,162$ taraf $4=0,163$ taraf $5=0,220$ taraf $6=0,224$ taraf $7=0,224$ taraf $8=0,224, \mathrm{kk}=3.97 \%$, nilai yang di ikuti huruf yang sama menunjukan perbedaan yang sangat nyata.

Perlakuan terbaik terhadap skor aroma yang disukai oleh panelis adalah perlakuan dengan suhu $90^{\circ} \mathrm{C}$ selama 9 menit (P2W2) dengan nilai skor uji aroma 3,18\%. Aroma dalam bahan makanan dapat ditimbulkan oleh komponen-komponen volatil, akan tetapi komponen volatil tersebut dapat hilang selama proses pengolahan terutama panas (Fellow, 1988 dalam Dewata, 2017).

\section{Rasa}

Pada uji organoleptik rasa teh daun kersen yaitu 2,75 (tidak suka) 3,44 (suka) dengan rerata yaitu 3,03 (netral). Hasil sidik ragam menunjukkan bahwa suhu penyeduhan $(\mathrm{P})$ berpengaruh sangat nyata $(\mathrm{P} \leq 0,01)$ dan lama penyeduhan $(\mathrm{W})$ berpengaruh tidak nyata $(P \geq 0,05)$ sedangkan interaksi dari kedua perlakuan $(P W)$ berpengaruh nyata $(P \leq 0,05)$ terhadap sensorik rasa teh daun kresen. Adapun grafik yang menunjukkan organoleptik warna terhadap teh daun kersen dapat dilihat pada Gambar 5.

Perlakuan terbaik terhadap skor rasa yang disukai oleh panelis adalah perlakuan dengan suhu $90^{\circ} \mathrm{C}$ selama 9 menit (P2W2) adalah 3,34\%. Perbedaan rasa suka ataupun tidak suka oleh panelis adalah tergantung kesukaan panelis terhadap masing-masing perlakuan dengan penambahan daun teh yang berbeda, sebab tingkat kesukaan terhadap suatu produk adalah relatif (Daroini, 2006). 


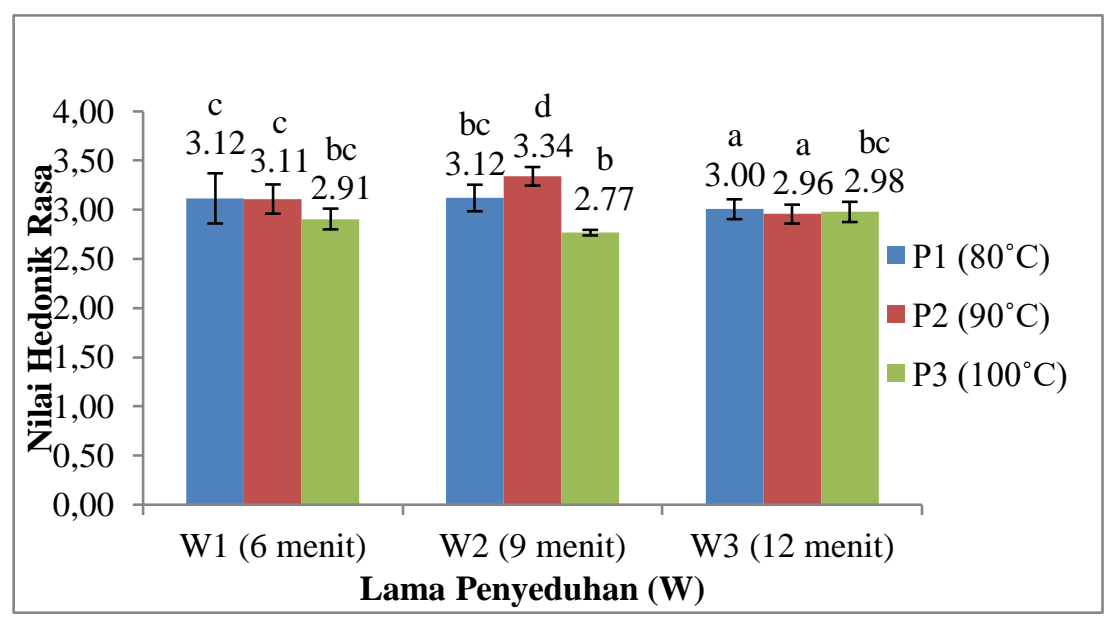

Gambar 5. Pengaruh lama waktu penyeduhan terhadap persentase $(\%)$ rasa teh daun kersen pada uji lanjut DMRT0.05 taraf $1=0,149$ taraf $2=$ 0,150 taraf $3=0,151$ taraf $4=0,151$ taraf $5=0,204$ taraf $6=0,208$ taraf $7=0,208$ taraf $8=0,208, \mathrm{kk}=3.88 \%$, nilai yang di ikuti huruf yang sama menunjukan perbedaan yang sangat nyata.

\section{Keseluruhan}

Pada uji organoleptik keseluruhan teh daun kersen yaitu 2,75\% (tidak suka) 3,40\% (suka) dengan rerata yaitu 3,11\% (netral). Hasil sidik ragam menunjukkan interaksi antara suhu penyeduhan dan lama penyeduhan $(\mathrm{PW})$ berpengaruh sangat nyata $(\mathrm{P} \leq 0,01)$ terhadap keseluruhan teh kersen. Adapun grafik yang menunjukkan organoleptik warna terhadap teh daun kersen dapat dilihat pada Gambar 6.

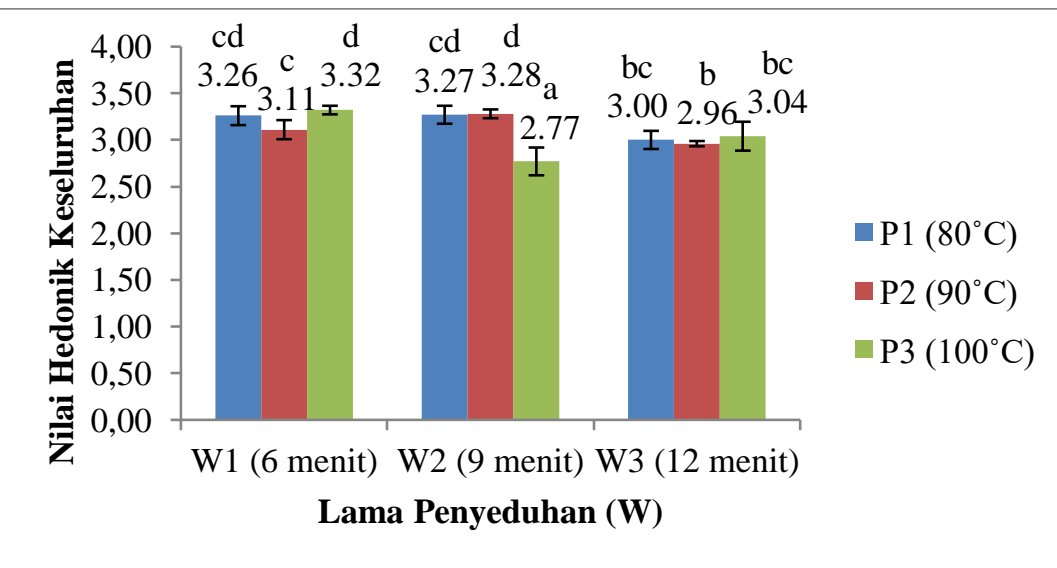


Gambar 6. Pengaruh lama waktu penyeduhan terhadap persentase (\%) keseluruhan teh daun kersen pada uji lanjut DMRT0.05 taraf $=$ 0,114 taraf $2=0,114$ taraf $3=0,115$ taraf $4=0,115$ taraf $5=0,156$ taraf $6=0,159$ taraf $7=0,159$ taraf $8=0,159, \mathrm{kk}=3.68 \%$, nilai yang di ikuti huruf yang sama menunjukan perbedaan yang sangat nyata.

Secara nilai keseluruhan panelis lebih menyukai teh daun kersen dengan interaksi suhu penyeduhan $80^{\circ} \mathrm{C}$ dan lama penyeduhan teh 6 menit (P3W1) dan interaksi suhu penyeduhan $90^{\circ} \mathrm{C}$ dan lama penyeduhan 9 menit (P2W2). Penilaian tertinggi pada teh daun kersen dengan suhu penyeduhan $90^{\circ} \mathrm{C}$ dan lama penyeduhan 9 menit (P3W2).

\section{KESIMPULAN DAN SARAN}

Adapun kesimpulan dari hasil penelitian ini adalah suhu penyeduhan mempengaruhi kadar tanin teh daun kersen. Kadar tanin tertinggi diperoleh pada suhu penyeduhan $100^{\circ} \mathrm{C}$. lama penyeduhan teh daun kersen juga mampu mempengaruhi aktivitas antioksidan. Aktivitas antioksidan tertinggi di peroleh pada waktu penyeduhan teh daun kersen 12 menit. Interaksi kedua antara suhu dan lama penyeduhan teh daun kersen berpengaruh sangat nyata terhadap aktivitas antioksidan teh daun kersen. Suhu dan lama penyeduhan berpengaruh sangat nyata terhadap hedonik warna seduhan teh daun kersen. Perlakuan yang disukai oleh panelis adalah suhu $80^{\circ} \mathrm{C}$ selama 6 menit dan suhu $90^{\circ} \mathrm{C}$ selama 9 menit. Suhu penyeduhan berpengaruh sangat nyata terhadap hedonik rasa seduhan teh daun kersen. Perlakuan yang disukai panelis adalah dengan suhu $90^{\circ} \mathrm{C}$ selama 9 menit.

\section{DAFTAR PUSTAKA}

Anjasari. 2016. Katekin Teh Indonesia: Prospek dan Manfaatnya. Fakultas Pertanian Universitas Padjajaran. Bandung. Jurnal Kultivasi 15(2): 99 - 106.

Binawati, D. K., dan Amilah, S. 2013. Effect of Cherry Leaf (Muntingia calabura L.) Bioinsecticides Extract Towards Mortality of Worm Soil (Agrotis ipsilon) and Armyworm (Spodoptera exiqua) on Plant Leek (Allium fistolum). Wahana, 61(2):5157.

Fajar, R. I., L.P. Wrasiati., L. Suhendra. 2018. Kandungan Senyawa Flavonoid dan Aktivitas Antioksidan Ekstrak Teh Hijau Pada Perlakuan Suhu Awal dan Lama Penyeduhan. Jurnal Rekayasa dan Manajemen Agroindustri 6(3):196-202

Fajriana, A., dan Priantinah, D. 2016. Pengaruh Corporate Social Responsibility, Keputusan Investasi dan Struktur Modal Terhadap Nilai Perusahaan. Jurnal Nominal. 5(2), 16-18.

Daroini, O. 2006. Kajian Proses Pembuatan Teh Herbal dari Campuran Teh Hijau (Camellia Sinensis) Rimpangan Bangle (Zingiber cassumunar Roxb.) dan Daun Caremai (Phylianthus acidus (I.) Skeels. Skripsi. Fakultas Pertanian IPB, Bogor.

Dewata, I.P., Wipradnyadewi, P.A.S., dan Widarta, I.W.R. 2017. Pengaruh Suhu dan Lama Penyeduhan Terhadap Aktivitas Antioksidan dan Sifat Sensoris Teh Herbal Daun Alpukat (Persea americana Mill.). Jurnal ITEPA 6(2):30-39. 
Ilfakah. 2017. Efektivitas antioksidan Daun Sirsak Dalam Menurunkan Nilai Asam Urat dan Keluhan Nyeri Pada Penderita Gout di Kelurahan Tamalanrea Makasar. Jurnal Ilmiah Farmasi - UNSRAT 6(2).

Jyosmita, K. C. 2015. Determination Of Tanin Contect By Tirtrimectric Method From Different Types Of Tea. International Journal India. (Diakses Pada 24 September 2015).

Nurul, M., S. Chadijah dan M. Qaddafi. 2018. Penentuan Suhu dan Waktu Optimum Penyeduhan Batang Teh Hijau (Camellia Sinensis L.) Terhadap Kandungan Antioksidan Kafein, Tanin, dan Katekin. Lantanida jurnal. 6(1): 1-102.

Sudarmanto, A. 2015. Program Pendampingan Teh Seduh dan Celup dari Daun Kersen Guna Menumbukan Kreatifitas Wirausaha Di Kelurahan Lamper Tengah Kecamatan Semarang Selatan Kota Semarang. DIMAS 15(1):79.

Soraya, N. 2007. Sehat dan Cantik Berkat Teh Hijau. Penebar Swadaya, Jakarta.

Tandean, A., V dan Jonathan. 2016. Pengaruh Tax Avoidance Terhadap Nilai Perusahaan Dengan Profitabilitas Sebagai Variabel Pemoderasi. Prosiding Seminar Nasional Multi Disiplin Ilmu \& Call for Papers UNISBANK, (2008), 703-708.

Yuningsih R., Samingan., Muhibbuddin. 2012. Pengaruh Berat dan Lama Waktu Penyeduhan Terhadap Kadar Kafein Teh. Jurnal Ilmiah Pendidikan Biologi, Biologi Edukasi 4(2):82-87. 